\title{
Tourism and conservation in Madagascar: The importance of Andasibe National Park
}

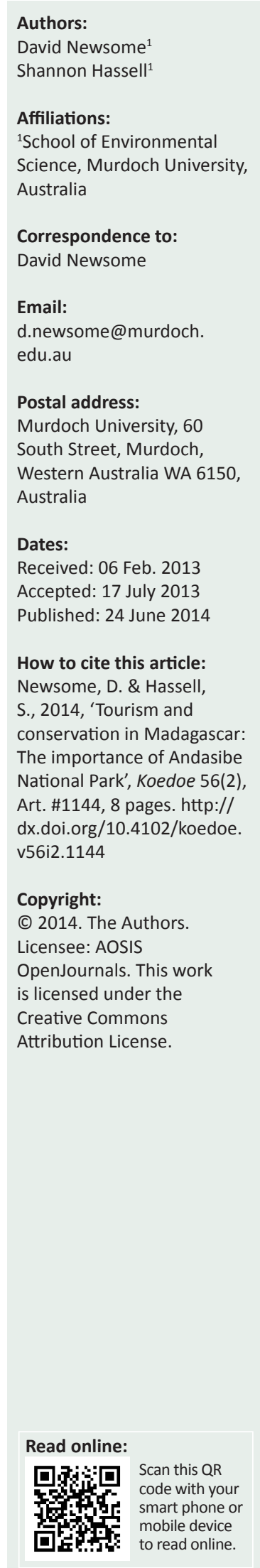

Madagascar is renowned for high levels of biodiversity and endemism. As a result of its unique flora and fauna, as well as the high levels of human threat to the environment, such as illegal clearing, hunting and political instability, it is a critical global conservation priority. Andasibe-Mantadia National Park in eastern Madagascar is one of the most popular protected areas visited by tourists. Observations carried out in 2011 showed that even though there were some negative impacts associated with natural-area tourism, the benefits to both the local communities and associated biological conservation outweighed the negatives. Natural-area tourism at Andasibe is well organised, with many local guide associations having partnerships with international organisations and 50\% of park fees going directly to local communities. Forest loss is a widespread problem in Madagascar, but at Andasibe the forest is valued for its ecological function and as a generator of profits from naturalarea tourism. Exploitation of the park was not observed. Andasibe is an example of how conservation and natural-area tourism can work together in Madagascar for the benefit of local communities and the environment. However, with the current unstable political climate and lack of adequate wider tourism and conservation planning frameworks, awakening to its potential as a leading conservation tourism destination will not be a simple task.

Conservation implications: This research demonstrated that ecotourism can be an effective means of achieving conservation objectives, whilst, at the same time, improving the livelihoods of local people. We caution, however, that governments can do a lot more to encourage and support the nexus between tourism and conservation.

\section{Introduction}

Ecological sustainability is a concept that has gained global attention in recent times, with landmark publications such as the Bruntland Report (World Commission on Environment and Development 1987) and the Rio declaration on environment and development (United Nations 1992). In response to the increasing pressure being placed upon the natural environment, aspects of the tourism industry and system have progressed to incorporate this concept. Tourism is a complex array of activities (e.g. see Mill \& Morrison 1992; Weaver \& Lawton 2006); however, for the purposes of exploring the context of tourism in Madagascar, it is defined as natural-area tourism which also encompasses ecotourism and wildlife tourism. Ecotourism is where attractions are nature-based, learning activities and outcomes are incorporated and attractions are managed for sustainability. Wildlife tourism is where the focus is centred on viewing and interacting with wildlife under natural conditions. Where such tourism aids in the protection of natural areas it is termed conservation tourism (Newsome, Moore \& Dowling 2013).

Conservation tourism (CT) can thus be viewed as a subset of ecotourism, where the activity acts as an instrument for biological conservation. Buckley (2010:2) defined it more specifically as 'commercial tourism which makes an ecologically significant net positive contribution to the effective conservation of biological diversity'. Whilst ecotourism has been defined in various ways (Blamey 1997; Ceballos-Lascuráin 1996; Donohoe \& Needham 2006; Fennell 2008; Harrison 1997; Weaver 2005, 2008), CT, however, has a more specific biological conservation focus. Conservation of the natural assets (e.g. birds, mammals and flora) on which it depends is often a defining tenet of ecotourism (Fennell 2008; Newsome et al. 2013; Weaver \& Lawton 2007) but it is not always considered essential (Buckley 2010), nor has tourism's actual contribution to conservation been scientifically studied and monitored in much depth in the literature (Kruger 2005; Weaver \& Lawton 2007). As the need for biological conservation and ecological sustainability becomes greater due to habitat loss, hunting wildlife, population increases and poverty, using a number of tools or instruments, such as tourism, can assist in achieving conservation goals.

The aim of this article is to explore the potential utility and role of natural-area tourism in conservation, with a specific focus on Madagascar. In particular, some recent personal observations 
from Andasibe-Mantadia National Park and surrounds are highlighted as evidence that natural-area tourism does work in conserving wildlife and their habitats. It is cautioned, however, that although Andasibe is a CT success story, much work remains to be done to realise the benefits evidenced at the national level in Madagascar.

\section{Tourism and environmental conservation}

Natural-area tourism, including its subsets ecotourism and $\mathrm{CT}$, holds the potential for a number of positive impacts to occur on a variety of levels. It generates foreign currency and creates opportunities for local employment, which, in less developed countries, is a key limiting factor in development (Mbaiwa 2008; Sinclair 1998). Kruger (2005) studied global cases of ecotourism and found that in those cases deemed sustainable, four main effects were present. These were increased conservation of the natural resource base, revenue creation by non-consumptive means increased for local communities, revenue increased at the regional and national level and positive changes of local communities towards conservation. Using natural resources, such as landscapes and focal species, as the primary tourism attraction can encourage greater appreciation and conservation attitudes amongst local communities who need an attractive natural environment for such tourism to be successful. For example, this has been applied successfully with tigers in India (Karanth et al. 2012; Sinha et al. 2012), sea turtles and whales in Australia (Wilson \& Tisdell 2003) and African wild dogs in South Africa (Lindsey et al. 2005). In places where there are competing economic interests, such as mining and logging, tourism can be a more sustainable use of natural resources in the long term (Briassoulis 2002; Curtin Sustainable Tourism Centre 2010). However, CT has its limitations and negative cases have been reported (Buckley 2010).

Green and Higginbottom (2001) grouped the potential impacts of humans on wildlife through natural-area tourism into three categories: disruption of activity, direct killing or injury and habitat alteration (including provision of food). Kruger (2005) and Lansing and De Vries (2007) also questioned ecotourism's role in conservation and whether it actually contributes towards conservation or if it is only a marketing ploy used by the tourism industry to capitalise on its popularity. Cases of abusing the 'eco' label ('green washing') are common (Fennell 2008; Self, Self \& Bell-Haynes 2010). This is further exacerbated by the lack of common knowledge of what exactly ecotourism entails, lack of a single global eco-certification system and the lack of political will to embrace sustainability principles (Kruger 2005; Self et al. 2010). Exploiting the very thing that tourists come to see is a concern and increased popularity can attract more tourists thereby increasing the chance of direct and indirect disturbances (Newsome, Dowling \& Moore 2005; Stem et al. 2003). Other examples include proliferations of unsustainable tourism infrastructure development (Sinha et al. 2012), removing other forms of wildlife (predators, forest cover) to more easily see focus wildlife (Tisdell \& Wilson 2012) and disturbances to wildlife such as disrupted courtship and mating, and finding food (Newsome et al. 2005; Newsome et al. 2013) which varies between species (Blumstein et al. 2005). Finding a balance between conserving the resource base on which CT depends and contributing to the economic, financial and social sustainability of the host community is an ongoing concern and requires careful, holistic management.

Madagascar is considered one of the world's biodiversity hotspots (Conservation International 2012). Yet, it has had a tumultuous political, social and environmental history which we now turn to discuss in the context and tourism and conservation.

\section{Madagascar as a natural-area tourism destination}

Madagascar is located off the east coast of Africa in the Indian Ocean and is the fourth largest island in the world. Owing to its long period of geographical isolation, it is characterised by extremely high wildlife endemism; of those that have been discovered, $100 \%$ of terrestrial mammals, $92 \%$ of reptiles and $100 \%$ of amphibians are unique to the island, with new species being continually discovered (Goodman \& Benstead 2003, 2005). The natural environment of Madagascar has been detrimentally impacted by humans as a result of habitat destruction, hunting and live capture of animals, with major negative flow on effects such as erosion and wide spread species extinctions (Goodman \& Benstead 2003, 2005; Grosvenor 1987; Mittermeier et al. 2010). Because of its high biodiversity, species endemism and level of human threat, Madagascar is a critical global conservation priority (Goodman \& Benstead 2003, 2005). The remaining natural environment is of great interest to tourists, with wildlife tourism being the most popular subset of naturalarea tourism interests (Christie \& Crompton 2003), especially with appealing species such as lemurs, chameleons, birds and baobab trees (Mittermeier et al. 2010; Pawliczek \& Mehta 2008). The remaining protected areas (PAs) are extremely important in both biological conservation and supporting wildlife for natural-area tourism. Niche wildlife tourism providers in the USA and Europe run organised tours to see wildlife in Madagascar, focusing on lemurs, birds and endemic plant life (Figure 1). The international profile of Madagascar's endemic wildlife has resulted in the development of accommodation, tourism services and tour guiding at wildlife hotspots such as Nosy Mangabe, Masoala National Park, Kirindy Forest, Berenty Private Reserve and Andasibe-Mantadia National Park.

\section{Protected areas in Madagascar}

As of 2011, there were 45 terrestrial PAs in Madagascar, including 19 national parks, 5 strict nature reserves and 21 special reserves (Wollenberg et al. 2011) (Figure 2). This was a considerable increase to the existing PA network, which can be attributed to the Malagasy government committing in 2003 to a tripling of PAs to approximately 5.5 million ha by 2008 (Pawliczek \& Mehta 2008; Wollenberg et al. 2011). Private and 


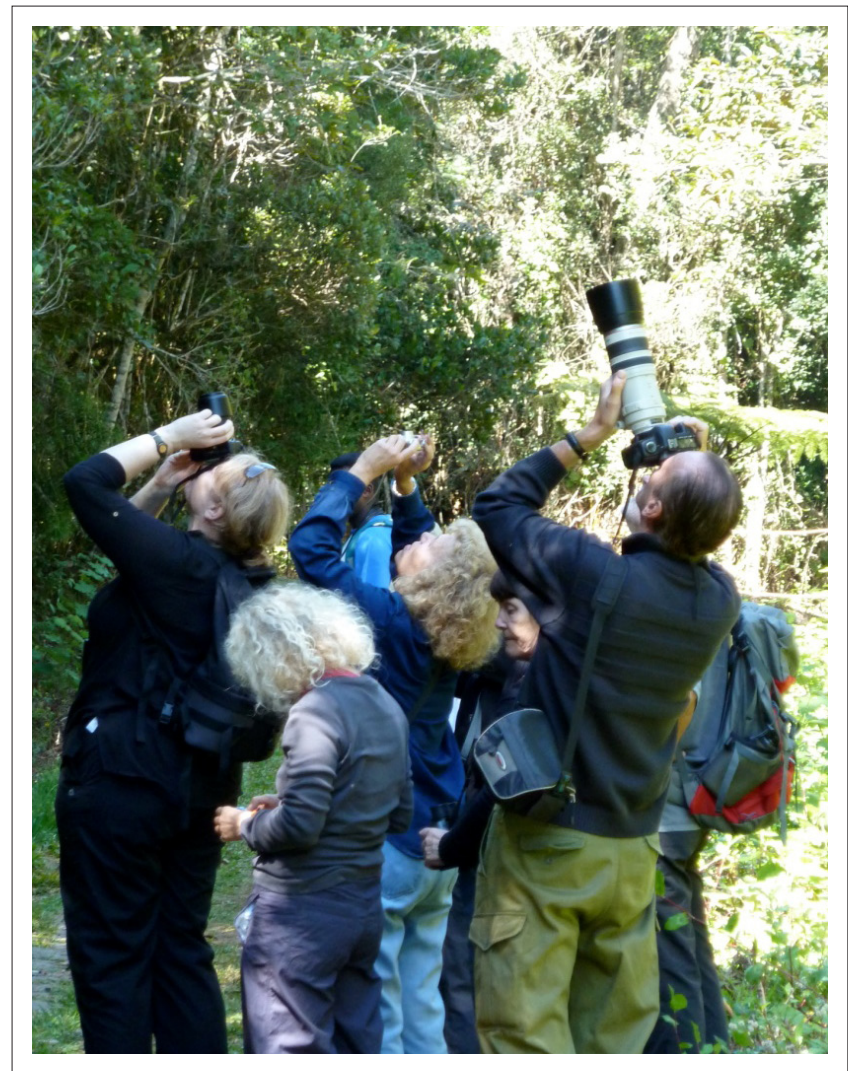

Source: Photograph by David Newsome

FIGURE 1: Small group of international tourists (niche tourism) viewing and photographing indri at Andasibe National Park.

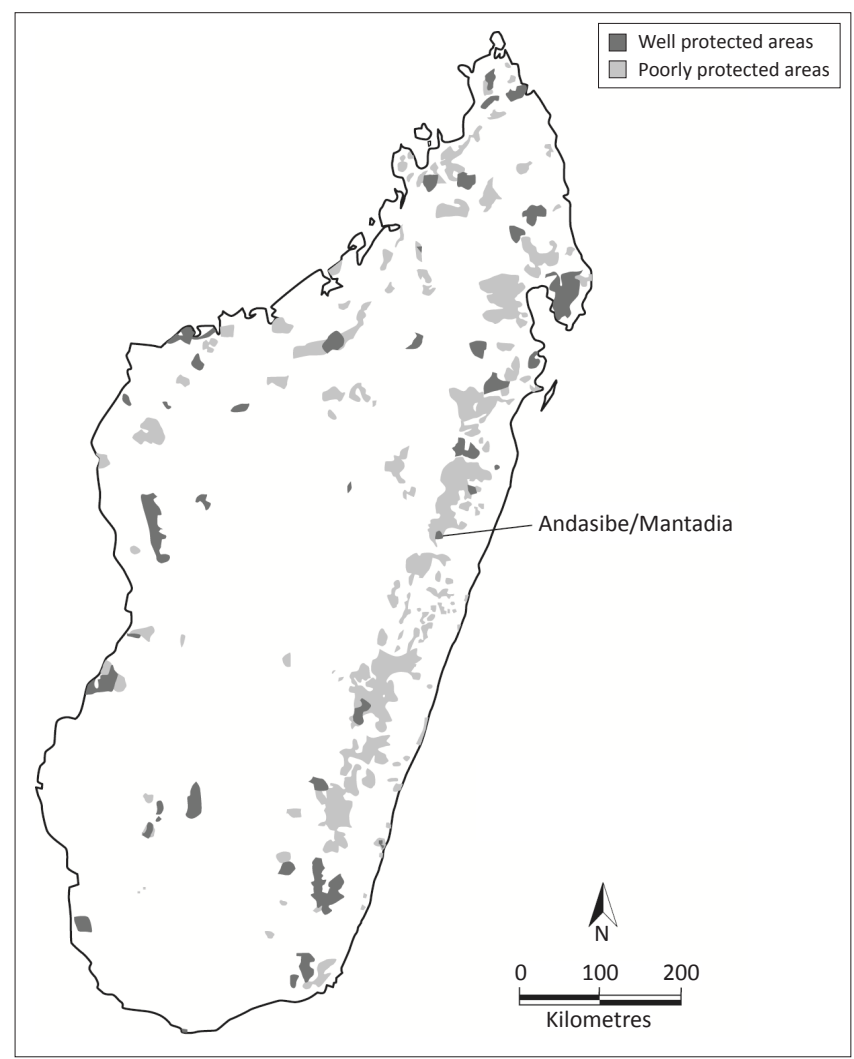

Source: Royal Botanic Gardens: Kew, 2012, Map 1: Protected areas of Madagascar, viewed 30 November 2012, from http://www.kew.org/gis/projects/madagascar/mad_parks.html

FIGURE 2: Map of the protected areas (national parks, nature reserves and special reserves) of Madagascar. Note that a significant portion of the protected area network is inadequately protected. community-owned PAs add to this public network (Buckley 2010). The then President, Marc Ravalomanana, saw the potential of the unique remaining natural environment to assist in his government's plans to further develop one of the poorest countries in the world and made conservation an important pillar of his Madagascar action plan (MAP) (Anon 2008; Presidency of Madagascar 2006). Despite the high biodiversity values of Madagascar and the naturalarea tourism potential, its conservation implications have not yet been fully realised (Christie \& Crompton 2003; Pawliczek \& Mehta 2008). There are, however, examples of positive ecotourism development, which may contribute to biological conservation.

\section{Tourism and environmental conservation in Madagascar}

Without endemic wildlife as an attractor, the natural-area tourism industry of Madagascar would struggle to survive. The impetus to conserve what remains is strong, at least with those who directly benefit from wildlife tourism, such as local communities adjacent to PAs and local guides, up to the government level (Ormsby \& Manni 2006; Presidency of Madagascar 2006). Even though many PAs are small in area, they support highly significant ecological communities that often occur nowhere else (Buckley 2010; Goodman \& Benstead 2003). Buckley (2010) stated that:

without the income from natural-area tourism, there is a much greater risk that the small areas of remnant vegetation will be cut for firewood and timber and used to graze cattle. (p. 47)

Such tourism focusing on viewing both flora and fauna shifts the attention from immediate unsustainable resource consumption to a potentially more sustainable nonconsumptive pattern of behaviour (Tisdell \& Wilson 2012).

This direct form of conserving the natural environment through natural-area tourism is complemented by other, more indirect methods. Ormsby and Mannie (2006) studied the role of ecotourism in providing an economic justification for conservation and also the role of guides in raising awareness and support for conservation in Masoala National Park, in the north-east of Madagascar. They found that local guides played a key role in communicating to tourists the importance of the environment, with $73 \%$ of surveyed guides stating that they wanted to pursue a career in guiding to help protect the environment. Training is rigorous and involvement with a guide association is compulsory, as is knowledge of a secondary language other than Malagasy or French (Newsome et al. 2013; Ormsby \& Manni 2006). In addition to educating tourists, the guides, in association with a local environmental youth group, broadcast a weekly hour-long radio programme at a local station. The aim is to communicate to local communities the importance of naturalarea tourism and conservation of the natural environment. One guide explained that many local people do not realise the biological and economic importance of Madagascar's environment. Masoala National Park also allocates half of park visitor entrance fees to local management committees 
to use for development projects of their choice (Ormsby \& Manni 2006). This further encourages the protection of the environment at the local level.

International commercial tour companies can also make a positive contribution to conservation through tourism. Buckley (2010) studied the company Natural Habitat Adventures (NHA) and their wildlife viewing tour of Madagascar (Natural Habitat Adventures 2012). NHA is an American ecotourism travel and tour company with a strong sustainability focus and a unique partnership with the World Wide Fund for Nature. It hires local guides at destinations, contributing to community social and economic development as well as ensuring that the tourists receive superior local knowledge. NHA utilises a variety of PAs for their tours, including private reserves. Similar economic incentives for conservation occur, such as developing markets for forest products in buffer zones between agricultural land and protected areas; however, landowners are not restricted by public land-clearing laws. Buckley (2010:50) stated that private land will remain undisturbed only if, (1) local land owners have no need or incentive to cut them or (2) if they gain greater net benefits by protecting them. According to Pawliczek and Mehta (2008:41), Madagascar is like a 'Sleeping Beauty' who is finally awakening to its naturalarea tourism potential. Wildlife tourism in this unique natural environment does not, however, guarantee a positive contribution towards conservation.

Stephenson (1993) studied the impacts of tourism at Perinet (now Andasibe-Mantadia National Park) and observed that despite the presence of designated walking paths, there was a proliferation of informal trails created by visitors and guides to get closer for wildlife viewing. This was causing an increase in erosion, trampling of native vegetation and favouring invasions of herbs, weeds and rats. Stephenson (1993) also reported that daily forest searches for animals such as the lemur Indri (Indri indri) were also causing animals to become habituated to humans and show no alarm in their presence. In a later study, Buckley (2010:51) reported incidences where wildlife was being exploited for profit by local people. To ensure sightings, some guides had illegally captured wildlife and both charged tourists to see these caged animals or had placed them in an easy to see spot so as to mislead tourists into believing they had 'discovered' the animal, for example a rare Tomato Frog, Dyscophus antongili that had been refrigerated to slow it down. Mittermeier et al. (2010) also reported the illegal capture and touristic exhibition of a Fossa (Cryptoprocta ferox), a native mammal made famous by the film Madagascar. What was most concerning was that the visitors to Perinet and the 'conservation tourists' on the organised trip did not seem to notice anything awry and seemed pleased to have photographic opportunities; potentially perpetuating an increase in both negative impacts and illegal actions which are counterproductive to biological conservation. Ill conceived and unmanaged wildlife tourism can have negative impacts on conservation; in Madagascar, however, the threats run much deeper than this.

\section{Threats to conservation in Madagascar}

The threats to conservation in Madagascar run deep and wide. Since humans colonised the island around 2000 years ago, it is estimated that only $10 \%-20 \%$ of the original forest cover remains (Conservation International 2012; Goodman \& Benstead 2003, 2005). This loss of habitat has caused widespread extinctions, erosion, loss of arable land and invasions of aggressive pest species (Durbin \& Ratrimoarisaona 1996; Mittermeier et al. 2010). Systemic issues such as poverty, traditional unsustainable farming methods (primarily slash and burn), a lack of conservation and ecotourism education and repeated political turmoil have played major roles in this loss of habitat and in the battle for biological conservation (Keane et al. 2011; Mittermeier et al. 2010; Ormsby \& Manni 2006; Pawliczek \& Mehta 2008). This is exacerbated by the variety of different ethnic groups, basic education levels and differences in values placed upon the natural environment (Scales 2012).

In the period prior to 2009, the Malagasy government made several attempts to increase the use of ecotourism as a development and conservation tool with various policy statements, with varying levels of success (Pawliczek \& Mehta 2008). These steps towards utilising natural-area tourism as a positive instrument for development were shattered following a coup in 2009, with tensions between the government and the then mayor of the capital, Antananarivo, leading to violent opposition and the presidents' eventual forced resignation from office (Ploch \& Cook 2012). Current tourism and conservation policies such as the MAP and the National environmental action plan were dismissed with the upheaval and tourism arrivals plunged from 375000 in 2008 to 163000 in 2009 (Mittermeier et al. 2010). International outrage at the unconstitutional taking of power froze international development aid, which was instrumental in the battle for sustainable development and biological conservation (Ploch \& Cook 2012; United States of America: Department of State 2012).

In addition to this, looting and poaching has been a major problem since the 2009 coup, with a poverty stricken public taking advantage of political instability by cutting down valuable rosewood (Dalbergia baronii) and others for export, trampling fragile habitats and hunting and eating bush meat, including endangered lemurs (Braun 2009; Mittermeier et al. 2010). Those employed in the natural-area tourism industry as guides and support were suddenly out of work and living in fear for their livelihoods (Braun 2009; Mittermeier et al. 2010). This was not the first time political instability has impacted both Madagascar's natural-area tourism industry as well as its biological conservation; in 1991 tourist arrivals dropped to approximately 35000 from 53000 in 1990 and illegal deforestation and poaching occurred as a direct result of political instability. Another political crisis in 2002 also abruptly halted tourism development (Durbin \& Ratrimoarisaona 1996; Pawliczek \& Mehta 2008; United States of America: Department of State 2012). 
It is widely understood that without the support of the government through policy, both the conservation tourism industry in Madagascar and the resource it depends on, as well as biological conservation in its own right, will be threatened (Buckley 2010; Durbin \& Ratrimoarisaona 1996; Mittermeier et al. 2010; Pawliczek \& Mehta 2008). In the closing section of Pawliczek and Mehta's (2008) paper, they saw Madagascar's natural-area tourism industry (and associated conservation efforts) at a crossroads between:

Unstrategic tourism development for a few with exploitation of natural resources and pursuing non-sustainable and rapid results to boost the country's development; or a harmonised mix of different forms of tourism (of which ecotourism is an important one) to develop the economy of the country by integrating the local population and improving their living standards, targeting a responsible and long-term vision in which nature resources will be exploited in a sustainable way. (p. 63)

This was a reflection of what Grosvenor, the then President of the National Geographic Society, said in the late 1980s (Grosvenor 1987). At that point, extinctions were rife, natural-area tourism was in its infancy and foreign scientists were only just being allowed onto the island to undertake research. Grosvenor (1987) closed his article by asking the question: 'Can Madagascar avoid a new wave of extinctions?' As an answer, he proposed:

Maybe. Severe poverty still grips the island's ten million people, and projections of continued forest losses are gloomy. But if there is a turn around, it will happen because of a commitment by the Malagasy government to protect the country's natural resources. (p. 5)

It has been 25 years since this statement was made and it seems as though this question remains largely unanswered.

Both Pawliczek and Mehta (2008) and Grosvenor (1987) understood that without political support, the conservation of the environment, and consequently the industries of ecotourism and CT that support it, will fail. Without public spending on PAs, enforced regulations on illegal natural resource consumption, international aid for conservation and development projects and with diminished trust in investing in Madagascan tourism, the future of conservation tourism in Madagascar is again in danger (Ormsby \& Manni 2006; Pawliczek \& Mehta 2008). In 2008, when Pawliczek and Mehta's paper was written, the future was looking brighter for Madagascar. 'Sleeping Beauty' was finally awakening to its ecotourism and CT potential and the positive step towards development was occurring. Unfortunately for the rich biological diversity, the remaining fragile flora and fauna communities, those species yet to be discovered and those communities who depend on natural-area tourism for their livelihood, due to political instability, the darker path at the crossroads seems to have been taken. Can this situation be turned around in the current political climate? Is CT still a viable tool for biological conservation? Recent observations made in Andasibe-Mantadia National Park point to a positive turn being made in the tumultuous history of natural-area tourism and conservation in Madagascar.

\section{The success of Andasibe through local community engagement and conservation support}

Andasibe-Mantadia National Park is $155 \mathrm{~km}^{2}$ in extent and comprises a range of vegetation types. The Andasibe section (formerly Perinet Reserve, 810 ha) comprises mid-altitude montane rainforest occurring at around 1000 m.a.s.l., whilst the Mantadia section consists of mid-altitude (800 m.a.s.l. 1300 m.a.s.l.) and lowland rainforest with an area of some $10000+$ ha. Faunal components include a rich assemblage of mammals (10 species of lemur), birds (couas, vangas, ground rollers and two species of asity), reptiles (five species of chameleons, including Parsons chameleon, leaf tailed gecko and Madagascar tree boa) and amphibians. Nature-based tourism activity and access is by guide-led excursions into the park along an extensive network of formed paths where bird watching and observations of lemurs and chameleons takes place. Night-spotting activities are not allowed in the park but are led by guides in adjacent forested areas. The park has historically received about 20000 visitors a year, with the Analamazaotra section of the park (where habituated indri occur) being one of the most visited sites in Madagascar (Mittermeier et al. 2010). Foreign visitors mostly occur in tour groups (numbers range from 5 or 10, up to 15) and at present there are few free independent travellers. Domestic tourism is increasing in importance with groups of up to 40 people at a time from schools and universities also visiting the park.

As already noted, Stephenson (1993) previously found significant problems in connection with unsustainable natural-area tourism practices at Perinet. A recent appraisal of the situation, however, found that many improvements have been made since the early 1990s and that most of the specific impacts observed by Stephenson (1993) were not readily detectable (Newsome et al. 2013). At the same time, as highlighted in other contexts earlier, there are some potential tourism impacts. Based on observations conducted in 2011, Newsome et al. (2013) additionally reported tourists leaving trails in order to locate and observe indri and other species of lemur. This tourist activity has caused a proliferation of informal trails and trampling of vegetation. Some tourists were observed to call out at the indri in order to gain the animals attention for photographic purposes. Sometimes there were up to 50 people at an indri sighting along with considerable turnover of visitors as people left and others joined the sighting during the viewing period that lasts from around 07:00 until around 12:30. Despite these impacts and the presence of humans, the habituated indri groups do not show any disturbance behaviour (A. Rakotonoely, pers. comm., 01 October 2011). In terms of the delivery of information and interpretation, the quality of guiding is variable and the main function of the guide appears to be in regard to locating and identifying species, but guides are also willing and able to answer questions. Nevertheless, the situation at Andasibe today must be viewed in the positive context of increased rainforest tourism globally. Furthermore, and given the situation of reduced impacts overall as described above, 
there is now more emphasis on the importance of tourism in conserving remnant patches of rainforest and increased stakeholder understanding of the principles of ecotourism and the professionalisation of tour guiding over the last 10 years.

Andasibe is managed according to a park management plan, but the actual details contained in the plan are difficult to obtain. Currently, the park has $40+$ rangers whose duties include permit delivery, protection via enforcement of regulations, support for scientists and tour guiding. Guides who are not rangers need approval to work in the park (Figure 3) and the park runs training courses for guides. The Guides Association of Madagascar (Natural Tour Guide Federation of Madagascar) is now 20 years old. Its main objective is to join tour guides into one association with the aim of training during the low season. The Association works with experts, for example botanists from Kew Gardens and experts from Birdlife International, and generally conducts courses lasting 3 days. However, courses can last for 1-2 weeks so that aspiring and junior guides can gain skills in the identification and ecology of plants, birds and reptiles with the aim of gaining a certificate or qualification which will aid them in gaining employment as tour guides.

At Andasibe, the local people, who are members of organised groups such as the Association des Guides d' Andasibe, the Tambata Guide Association and the Mitsingo local community, supply the majority of tour guiding services. The Mitsingo local community is particularly involved in conservation work such as native tree planting and the implementation

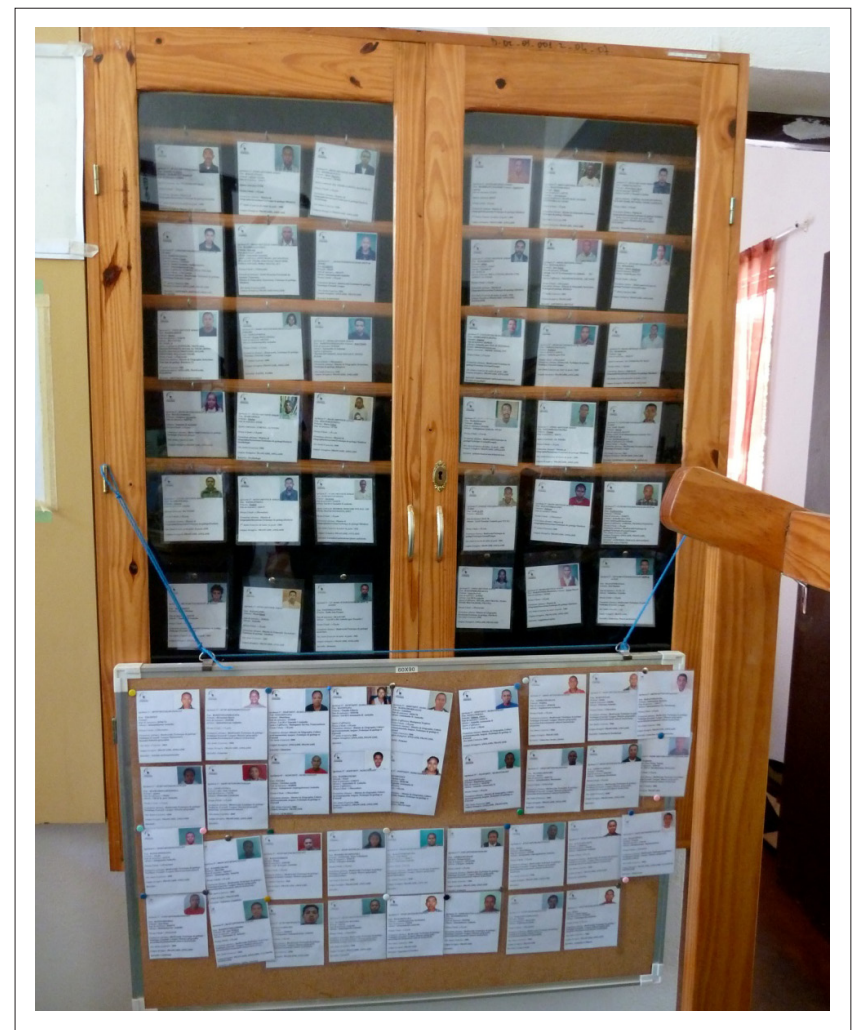

Source: Photograph by David Newsome

FIGURE 3: Cabinet located at Andasibe National Park with records of approved and registered tour guides working in the park. The majority of guides live in the village of Andasibe. of a corridor project between Mantadia National Park and Andasibe National Park. The Mitsingo Forest Station is a community reserve created by German conservationist, Mr Rainer in 1992-1993. The local community surrounding the park, such as Mitsingo, works with international nongovernmental organisations and the guides association that was originally created to help protect the forest. In 2009, Vanga was developed as an English-speaking guide association with a focus on wildlife interpretation and conservation. The plan was to share knowledge especially between local guides with particular emphasis on the delivery of good interpretation. Training is conducted during the low season and there is collaboration with experts such as botanists from the Missouri Botanical Gardens and herpertologists from the capital city, Antananarivo. It is estimated that there are at least 70, and as many as 100, guides working in AndasibeMantadia National Park, most of which are from the local community of Andasibe village (Mittermeier et al. 2010).

The economic and positive livelihood benefits of tourism to the local community living in and around Andasibe village (population c. 14 000) are considerable (D. Newsome, pers. obs., 01 October 2011). Although no actual amount has been directly calculated, there are tangible indicators (protection of community forest, improved road conditions and village services) that demonstrate positive financial benefits that are gained from a percentage $(50 \%)$ of park fees that flows from the park to the local community and employment of local people as guides, as well as the creation of ecotourismrelated jobs. At Andasibe, this has resulted in funding for road upgrades (Figure 4) and other infrastructural developments such as schools, market place development, a dispensary and piped water. There is employment as guides (70 from Andasibe village) and employment opportunities for the local community to work in hotels (in 1995 there was one hotel, compared with 10 hotels in 2011), in retail and as drivers. Given these opportunities to earn a living directly associated with natural-area tourism there is a major incentive to protect

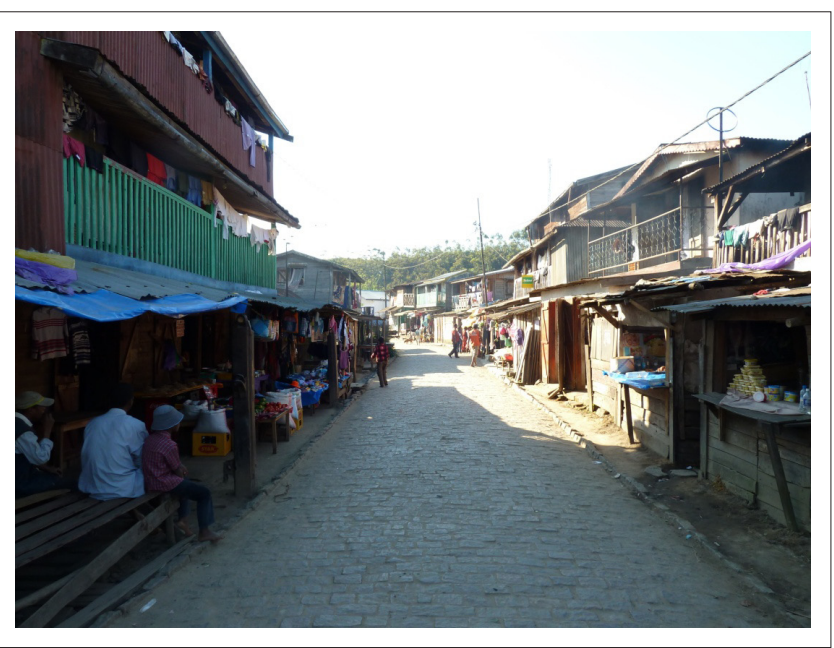

Source: Photograph by David Newsome

FIGURE 4: Main access road in Andasibe village which has been improved via funding from tourism profits. Roads in Madagascar can be extremely rutted with many pot holes, which become waterlogged when wet and shedding dust when dry. Hardening and sealing main access roads is a considerable improvement to village access and functionality. 


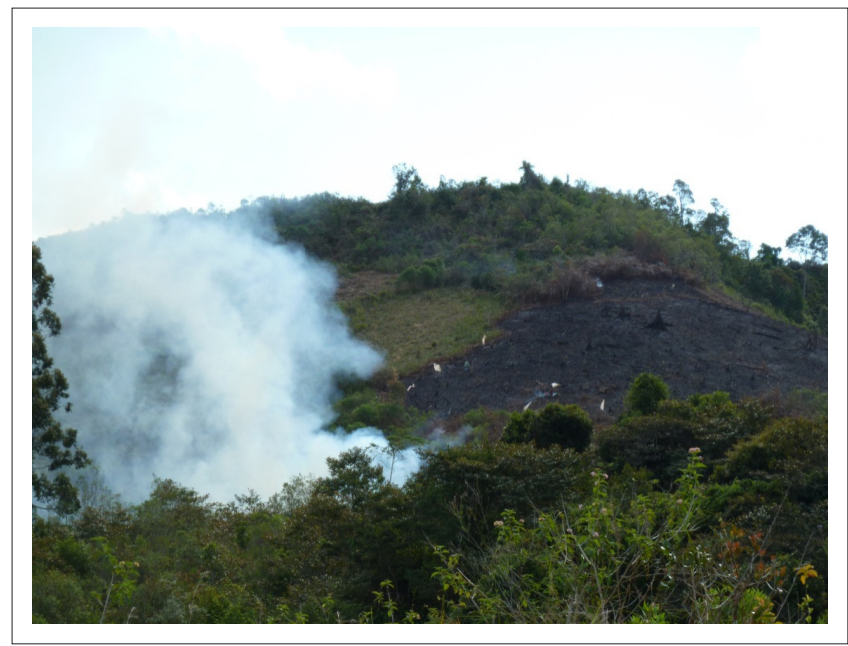

Source: Photograph by David Newsome

FIGURE 5: Slash and burn agriculture in the vicinity of Andasibe National Park.

the forest and wildlife. Forest loss is a widespread problem (Figure 5) in Madagascar, but at Andasibe the forest is valued for its ecological function as a generator of profits from naturalarea tourism and exploitation of the park was not observed (D. Newsome, pers. obs., 01 October 2011). In addition to international tourists (Figure 1), the local community, school groups and university students are now part of the visitor profile at Andasibe and such local tourism further engages Malagasy to realise the importance of wildlife in their lives and the need to conserve habitat for tourism purposes.

\section{Conclusion}

Natural-area tourism, comprising ecotourism and wildlife tourism, has the potential to contribute towards biological conservation through directly benefitting adjacent local communities (Alexander 2000; Buckley 2010; Burns \& Sofield 2001). This can be achieved through increased economic exchange via employment and funding for infrastructure and buildings, as observed at Andasibe-Mantadia National Park in eastern Madagascar. The promotion, operation of ecotourism and the quality of guiding are fostered by Mitsinjo and the local Andasibe guides association who work in both parks. The role and value of the guides associations that are derived from the local community in promoting community-based conservation cannot be underestimated. Not only are guides working within the borders of Andasibe, they are also conducting night tours on the perimeter of the PA. Profits from this provide a strong incentive to protect the forest not only within but outside designated borders, which expands the reach of conservation for both itself and for tourism purposes. Although there were some observed environmental impacts associated with locating and viewing lemurs at Andasibe, as similarly observed by Stephenson (1993), the benefits of nature-based tourism in biological conservation far outweigh any of its impacts, such as trampling the undergrowth. Because ecotourism is firmly established at Andasibe, this, in itself, provides opportunities for ecotourism-related impacts to be studied, monitored and managed in the longer term, which should be an objective in all forms of sustainable tourism, including CT.
Although local people can see the benefits of wildlife tourism, they still need to be engaged and educated for biological conservation to be more fully realised. This extension of tourism into educating the local community about the need for biological conservation was shown by Ormsby and Manni (2006) to be occurring with park guides broadcasting weekly radio programmes to the local communities adjacent to Masoala National Park. This was not observed at Andasibe; however, this extension of the guide's responsibilities could potentially be applied to further the positive outcomes of biological conservation at Andasibe. With the support of international partners, such as Kew Gardens (UK) and Missouri Botanical Gardens (USA), further programmes such as this could be put into place, extending the reach of natural-area tourism to assist with biological conservation.

Larger, systemic issues such as poverty, the need for land for housing and agriculture and the reliance on forest products remain and have been made even greater by the recent political crisis in 2009. However, the case of Andasibe demonstrates that natural-area tourism can be effective in contributing towards biological conservation and poverty alleviation for people who live near important biodiversity and protected areas. It thus seems that Madagascar is now repeating the history of increasing tourism arrivals and development along with the associated recognition of the importance of the environment. At the same time, however, it appears that the hard work that has been put in place is being jeopardised through policies such the MAP being forgotten and unimplemented.

Buckley (2010) made the point that an adequate conservation framework needs to be in place for tourism to assist with CT goals. This is true in that conservation frameworks in Madagascar have been created but have not had appropriate political space to be implemented. The previous government had attempted to do this by expanding the PA network in Madagascar, but large portions of this remain poorly protected (Goodman \& Benstead 2003). At the government policy level, much work remains to be done and the ecotourism potential of Madagascar's wildlife needs to be valued further. Andasibe National Park is an example of how conservation and tourism can work together in Madagascar for the benefit of both local communities and the environment. However, as Pawliczek and Mehta (2008) have indicated, Madagascar is like a 'Sleeping Beauty' with great potential for CT, but with so many ongoing threats, awakening to this potential is unfortunately not a simple task.

\section{Acknowledgements}

We thank Alain Rakotonoely for helpful discussions and assistance in the field.

\section{Competing interests}

The authors declare that they have no financial or personal relationships that may have inappropriately influenced them in writing this article. 


\section{Authors' contributions}

D.N. (Murdoch University) conceived the article, conducted the fieldwork, wrote $50 \%$ of the text and supplied the diagrams. S.H. (Murdoch University) conducted a literature review of conservation tourism and investigated the issues surrounding tourism and conservation in Madagascar.

\section{References}

Anon., 2008, 'Environment: Madagascar', Africa Research Bulletin: Economic, Financial and Technical Series 45(7), 17914-17915. http://dx.doi.org/10.1111/j.1467and Technical Series

Alexander, S.E., 2000, 'Resident attitudes towards conservation and black howler monkeys in Belize: The Community Baboon Sanctuary', Environmental Conservation 27(4), 341-350. http://dx.doi.org/10.1017/S0376892900000394

Blumstein, D.T., Fernandez-Juricic, E., Zollner, P.A. \& Garity, S.C., 2005, 'Inter-specific variation in avian responses to human disturbance', Journal of Applied Ecology 42(5), 943-953. http://dx.doi.org/10.1111/j.1365-2664.2005.01071.x

Blamey, R.K, 1997, 'Ecotourism: The search for operational definition', Journal of Sustainable Tourism 5(2), 109-130.

Braun, D., 2009, Lemurs, rare forests threatened by Madagascar strife, viewed 10 December 2012, from http://newswatch.nationalgeographic.com/2009/03/23/ lemurs_threatened_by_madagascar_strife/

Briassoulis, H., 2002, 'Sustainable tourism and the question of the commons', Annals of Tourism Research 29(4), 1065-1085. http://dx.doi.org/10.1016/S0160-7383 (02)00021-X

Buckley, R., 2010, Conservation tourism, CAB International, Wallingford. http://dx.doi org/10.1079/9781845936655.0000

Burns, G.L. \& Sofield, T.H.B., 2001, The host community: Social and cultural issues concerning wildlife tourism, Wildlife Tourism Research Report Series 4, Cooperative Research Centre for Sustainable Tourism, Gold Coast.

Ceballos-Lascuráin, H., 1996, Tourism, ecotourism and protected areas: The state of nature-based tourism around the world and guidelines for its development, IUCN, Cambridge.

Christie, I.T. \& Crompton, D.E., 2003, Republic of Madagascar: Tourism sector study, viewed 03 December 2012, from http://www.worldbank.org/afr/wps/wp63.pdf

Conservation International, 2012, Where we work: Madagascar and the Indian Ocean islands, viewed 06 December 2012, from http://www.conservation.org/where/ priority_areas/hotspots/africa/Madagascar_and_the_Indian_Ocean_Islands/ Pages/default.aspx

Curtin Sustainable Tourism Centre, 2010, Kimberely whale coast tourism: Opportunities and threats, viewed 20 November 2012, from http://www.wilderness.org.au/pdf/ Kimberley_WhaleCoast_Report.pdf

Donohoe, H.M. \& Needham, R.D., 2006, 'Ecotourism: The evolving contemporary definition', Journal of Ecotourism 5(3), 192-210. http://dx.doi.org/10.2167/joe152.0

Durbin, J.C. \& Ratrimoarisaona, S.-N., 1996, 'Can tourism make a major contribution to the conservation of protected areas in Madagascar?', Biodiversity \& Conservation 5, 345-353. http://dx.doi.org/10.1007/BF00051778

Fennell, D., 2008, Ecotourism, 3rd edn., Routledge, Abingdon.

Goodman, S.M. \& Benstead, J.P., 2003, The natural history of Madagascar, Chicago University Press, Chicago.

Goodman, S.M. \& Benstead, J.P., 2005, 'Updated estimates of biodiversity and endemism for Madagascar', Oryx 39(1), 73-77. http://dx.doi.org/10.1017/S0030605305000128

Green, R. \& Higginbottom, K., 2001, The negative effects of wildlife tourism on wildlife, Wildlife Tourism Research Report Series 5, viewed 06 December 2012, from http://
www.crctourism.com.au/wms/upload/Images/Disc\%20of\%20images\%20and\%20 www.crctourism.com.au/wms/upload/Images/Disco
PDFs/for\%20bookshop/Documents/5green3.pdf

Grosvenor, G.M., 1987, 'Madagascar: A lot to lose', National Geographic 172, 5.

Harrison, D., 1997, 'Ecotourism in the South Pacific: The case of Fiji', in World Ecotour '97 Abstracts Volume, p. 75, BIOSFERA, Rio de Janiero.

Karanth, K.K., DeFries, R., Srivathsa, A. \& Sankaraman, V., 2012, 'Wildlife tourists in India's emerging economy: Potential for a conservation constituency?', Oryx 46(3), 382-390. http://dx.doi.org/10.1017/S003060531100086X

Keane, A., Ramarolahy, A.A., Jones, J.P.G. \& Milner-Gulland, E.J., 2011, 'Evidence for the effects of environmental engagement and education on knowledge of wildlife laws in Madagascar', Conservation Letters 4(1), 55-63. http://dx.doi.org/10.1111/ j.1755-263X.2010.00144.x

Kruger, O., 2005, 'The role of ecotourism in conservation: Panacea or Pandora's box?' Biodiversity \& Conservation 14(3), 579-600. http://dx.doi.org/10.1007/s10531004-3917-4
Lansing, P. \& De Vries, P., 2007, 'Sustainable tourism or marketing ploy?', Journal of Business Ethics 72(1), 77-85. http://dx.doi.org/10.1007/s10551-006-9157-7

Lindsey, P.A., Alexander, R.R., Du Toit, J.T. \& Mills, M.G.L., 2005, 'The potential contribution of ecotourism to African wild dog Lycaon pictus conservation in South Africa', Biologica Conservation 123(3), 339-348. http://dx.doi.org/10.1016/j.biocon.2004.12.002

Mbaiwa, J.E., 2008, 'The realities of ecotourism development in Botswana', in A. Spenceley (ed.), Responsible tourism: Critical issues for conservation and development, pp. 205-223, Earthscan, London.

Mill, R.C. \& Morrison, A.M., 1992, The tourism system, Prentice Hall, Englewood Cliffs.

Mittermeier, R.A., Louis, E.E. Jnr, Richardson, M., Schwitzer, C., Langrand, O., Rylands, A.B. et al., 2010, Lemurs of Madagascar, 3rd edn., Conservation International, Arlington.

Natural Habitat Adventures, 2012, Ultimate Madagascar adventure, viewed 10 December 2012, from http://www.nathab.com/africa/wild-madagascar/

Newsome, D., Dowling, R.K. \& Moore, S.A., 2005, Wildlife tourism, Channel View Publications, Clevedon.

Newsome, D., Moore, S.A. \& Dowling, R.K., 2013, Natural area tourism: Ecology, impacts and management, 2 nd edn., Channel View Publications, Clevedon.

Ormsby, A. \& Manni, K., 2006, 'Ecotourism benefits and the role of local guides at Masoala National Park, Madagascar', Journal of Sustainable Tourism 14(3), 271-287. http://dx.doi.org/10.1080/09669580608669059

Pawliczek, M. \& Mehta, H., 2008, 'Ecotourism in Madagascar: How a sleeping beauty is finally awakening', in A. Spenceley (ed.), Responsible tourism: Critical issues for conservation and development, pp. 41-68, Earthscan, London.

Ploch, L. \& Cook, N., 2012, Madagascar's political crisis, viewed 30 November 2012 from http://www.fas.org/sgp/crs/row/R40448.pdf

Presidency of Madagascar, 2006, Madagascar action plan, viewed 03 December 2012 from http://siteresources.worldbank.org/MADAGASCAREXTN/Resources/MAP MADAGASCAR.pdf

Royal Botanic Gardens: Kew, 2012, Map 1: Protected areas of Madagascar, viewed 30 November 2012, from http://www.kew.org/gis/projects/madagascar/mad_parks. $\mathrm{html}$

Scales, I.R., 2012, 'Lost in translation: Conflicting views of deforestation, land use and identity in western Madagascar', The Geographical Journal 178(1), 67-79. http:// dx.doi.org/10.1111/j.1475-4959.2011.00432.x, PMid:22413174

Self, R.M., Self, D.R. \& Bell-Haynes, J., 2010, 'Marketing tourism in the Galapagos Islands: Ecotourism or greenwashing?', International Business and Economics Research Journal 9(6), 111-126.

Sinclair, M.T., 1998, 'Tourism and economic development: A survey', The Journal of DevelopmentStudies 34(5), 1-51. http://dx.doi.org/10.1080/00220389808422535

Sinha, B.C., Qureshi, Q., Uniyal, V.K. \& Sen, S., 2012, 'Economics of wildlife tourism: Contribution to livelihoods of communities around Kanha tiger reserve, India', Journal of Ecotourism 11(3), 207-218. http://dx.doi.org/10.1080/14724049.201 Journal of

Stem, C.J., Lassoie, J.P., Lee, D.R. \& Deshler, D.J., 2003, 'How "eco" is ecotourism? A comparative case study of ecotourism in Costa Rica', Journal of Sustainable Tourism 11(4), 322-347. http://dx.doi.org/10.1080/09669580308667210

Stephenson, P.J., 1993, 'The impacts of tourism on nature reserves in Madagascar: Perinet, a case study', Environmental Conservation 20, 262-265. http://dx.doi. org/10.1017/S0376892900023067

Tisdell, C. \& Wilson, C., 2012, Nature-based tourism and conservation: New economic insights and case studies, Edward Elgar, Cheltenham.

United Nations, 1992, Report of the United Nations conference on environment and development, viewed 25 November 2012, from http://www.un.org/documents/ $\mathrm{ga} /$ conf151/aconf15126-1annex1.htm

United States of America: Department of State, 2012, Background note: Madagascar, viewed 30 November 2012, from http://www.state.gov/r/pa/ei/bgn/5460.htm

Weaver, D.B., 2005, 'Comprehensive and minimalist dimensions of ecotourism', Annals of Tourism Research 32(2), 439-455. http://dx.doi.org/10.1016/j.annals.2004.08.003 Weaver, D.B., 2008, Ecotourism, 2nd edn., Wiley Australia, Milton.

Weaver, D.B. \& Lawton, L.J., 2006, Tourism management, Wiley Australia, Milton.

Weaver, D.B. \& Lawton, L.J., 2007, 'Twenty years on: The state of contemporary ecotourism research', Tourism Management 28(5), 1168-1179. http://dx.doi.org/ 10.1016/j.tourman.2007.03.004

Wilson, C. \& Tisdell, C., 2003, 'Conservation and economic benefits of wildlife-based marine tourism: Sea turtles and whales as case studies', Human Dimensions of Wildlife 8(1), 49-58. http://dx.doi.org/10.1080/10871200390180145

Wollenberg, K.C., Jenkins, R.K.B., Randrianavelona, R., Ramilamanana, R., Ralisata, M., Ramanandraibe, A. et al., 2011, 'On the shoulders of lemurs: Pinpointing the ecotouristic potential of Madagascar's unique herpetofauna', Journal of Ecotourism 10(2), 101-117. http://dx.doi.org/10.1080/14724049.2010.511229

World Commission on Environment and Development, 1987, Our common future, Oxford University Press, New York. 